\title{
Research on the Relationship of Media Attention, Stock Liquidity and Stock Price Informativeness: Based on the Data of Listed Company on GEM of China
}

\author{
Ningbo Cao \\ Financial Department, Economics School, Jinan University, Guangzhou, China \\ Email: cningbo@foxmail.com
}

How to cite this paper: Cao, N.B. (2017) Research on the Relationship of Media Attention, Stock Liquidity and Stock Price Informativeness: Based on the Data of Listed Company on GEM of China. Modern Economy, 8, 51-77.

http://dx.doi.org/10.4236/me.2017.81005

Received: December 9, 2016

Accepted: January 14, 2017

Published: January 17, 2017

Copyright $\odot 2017$ by author and Scientific Research Publishing Inc. This work is licensed under the Creative Commons Attribution International License (CC BY 4.0).

http://creativecommons.org/licenses/by/4.0/

\begin{abstract}
GEM stocks are more susceptible to the attention of news media because of their liquidity and high risk characteristics. This paper uses Baidu News search and the data of companies listed on GEM from 2009 to 2015 to investigate the impact of media attention and stock liquidity on stock price information content respectively and the impact of stock liquidity on the relationship between media attention and stock liquidity. The results show that with the number of media news coverage increasing and stock liquidity accelerating, stock information content will also be improved; further studies find that with the acceleration of stock liquidity, liquidity weakens the positive relationship between media attention and shares information content.
\end{abstract}

\section{Keywords}

Media Attention, Stock Liquidity, Stock Price Information Content

\section{Introduction}

The information content of share price refers to characteristics information of the company, which determines the effectiveness of the stock price signal transmission mechanism, affecting the allocation of resources in stock market, representing the level of market efficiency. The classical theory on market efficiency suggests that the stock price has already contained all available information, so market news have no effect on the stock price fluctuations. Lots of literatures deny this view, and they argue that the media information affects the volatility of stock prices by influencing the trading behavior of investors; the information of corporate enters the stock price with investors' information arbi- 
trage behavior, thus affecting the information content of stock price.

The capital market in China has always been regarded as a "policy market" where the implicit endorsement of the government on the stock market makes the stock price rise or fall together more frequently. Compared with the other 40 major economies in the world, the stock price information content of China is only the second from bottom (Morck and Yeung, et al. [1]). The low information content of the stock price is closely related to the information efficiency of capital market. In recent years, with the speeding up of the marketization process, the perfection of the system construction and the improvement of investor's self-protection consciousness, the listed companies in China have also improved the information disclosure and investor relations, and the market information efficiency has obviously improved. However, the information environment of China's securities market is still relatively poor, compared with the mature capital markets. On the one hand, the small and medium investors, because of a lack of analysis of the target company, especially a lack of the needs of accounting information, are reluctant to disclose accurate and transparent information. On the other hand, with the change of market environment, false statements and the means to conceal the facts are more secretive, and are difficult to be perceived by the regulators, which harm the interests of the majority of investors. As an important information disclosure and market supervision mechanism in the capital market, the news media, to some extent, affects the information environment of the capital market. It is of great practical significance to study the impact of news media on the information content of stock price, which will also further regulate the role of news media in capital market and enhance the information efficiency of China's capital market.

With the development of information technology and the popularity of mobile Internet, the media information's timeliness, the communication breadth and the depth of the content are significantly improved. Media news coverage has become an important link between enterprises, markets and investors, and media attention has more and more influence on social and economic life. In the West, media is often seen as a "Fourth Right", which is independent of legislation, administration and justice. In China, with the development of cultural industry, the news media has also shown an unprecedented active state, what's more, the function of media in the capital market has also been concerned by regulators. In July 2016, the Shanghai Stock Exchange published "The News Briefing Guidelines of Restructuring of Listed companies" to require restructuring of listed companies to hold a media briefing, and the first trial meeting in GEM should be open to the further media-developing areas where the news media played the role of information disclosure and public supervision. The news media plays a very important role in China's securities market. The media is not only an important supplement to the information dissemination of listed companies, but also a pioneer in the reform of the information environment in securities market. As the information intermediaries of the capital market, the news media collect, collate and publish information, provide the company cha- 
racteristics information for the public, and effectively alleviate the information asymmetry between managers and investors and the uneven information of different investors. More and more investors can make use of the information of the company to make decisions, thus affecting the information content of stock price (Luo J. H. and Cai D. [2]; Lee Y. Z. and Xu Q. F. [3]).

The study of capital market information efficiency can't be separated from the study of stock liquidity. Company-specific information is more frequently incorporated into stock prices as investors' trade more often. Investors trade generally follow the following logic, at first, investors obtain the characteristics information about listed companies, based on which the investors make judgments on the investment value of the company, and compare with the current market price, to buy the underestimated stocks or sell the overvalued ones. Frequent trading makes the company characteristics of information can be timely, fully and accurately reflected in the company's share price, affecting the stock price information content. Under normal circumstances, the transaction cost of high liquidity stock is lower, and more susceptible to arbitrage investors, to achieve information arbitrage, thus affecting its stock price information content. In addition, the media always pay much more attention to those stocks having fast liquidity. Then for stocks are different in liquidity, the relationship between media coverage and the content of information will differ.

After 10 years of brewing, the opening of China's GEM attracted extensive attention. The first trial meeting is to open the media, reflecting the focus of regulators on the dissemination function of the press, while the news media's omnidirectional, multi-level reports on the GEM Companies also play a role in the changes of GEM market. For small and medium investors, media news coverage is the primary way to access investment information (Barber and Odean [4]). Zhang, et al. [5] believe that the retail investors' trade mainly based on the press. On October 30, 2014, Shenzhen Stock Exchange Financial Innovation Laboratory released the "GEM Fifth Anniversary's Investor Structure and Behavior Analysis Report", shows that individual investors are still the main investors in the GEM. At the same time, in March 2015, the Shenzhen Stock Exchange released the "Survey of Individual Investors in 2014", the survey shows that compared with non-GEM investors are more dependent on acquaintances to recommend shares, GEM investors pay more attention to their own information to do comprehensive judgment. In addition, the turnover of the GEM record highs, these conditions laid a foundation for the paper to study the relationship between media attention and the GEM stock price information content, and the impact of stock liquidity on this relationship.

At present, the discussion of the role of news media in the capital market is a hot topic, but the relationship between the media attention and the information content of the stock price is still rare. In the existing literature on the relationship between media attention and stock price information content, the research object is usually the A-share market, and there is no special study on the GEM. Further, in empirical analysis, researchers directly use both proxy variables to 
conduct regression analysis; no one has researched from the view of stock liquidity. This paper based on that the individual investors are the majorities in the GEM, and individual investors are much more susceptible to the impact of mass media, and the high liquidity characteristics of the GEM, further analysis the relationship between the media attention and stock price information content in the GEM, and the impact of stock liquidity on this relationship.

This paper follows the logic of information economics and behavioral economics, uses the study of Rao Y. L., et al. (2010) [6], Luo J. H. and Cai D. (2013) [2], Yang J., et al. [7] for reference, measures media attention with the number of news articles whose titles contain the name of the stock of the sample company in Baidu News Advanced Search, measures the information content of the stock price with the stock non-synchronization index, uses the turnover rate to measure the stock liquidity, by studying the relationship between the number of media news reports, liquidity and stock price information content of GEM and the impact of stock liquidity on the relationship between media attention and stock price information content, to further discusses the impact mechanism of information environment on stock price information content in capital market of China.

The main content and the structure of the thesis are as follows: in the part of instruction, it mainly concerns study background, content, method, value of this article. The second part is the literature review. The third part is the theoretical analysis, and put forward the hypothesis of the paper. The fourth part introduces the sample, data, variables and empirical model. The fifth part is the result of empirical study, including descriptive statistical analysis, regression analysis and endogenous test. The last part is the conclusion.

\section{Theory Analysis and the Research Hypothesis}

Although investors have various accesses to investment information, still the press is an important way to expose "non-public information" or even the only channel (Tan S. T., et al. [8]). Other channels such as field research, analyst research and so on are transformation of the public information to some extent.

At present, there are few researches on the relationship between media attention and stock price information at home and abroad, and the viewpoints are not consistent. Have summarized the foreign researches, we can find out that the media reports may have a positive or negative impact on the information content of stock price. In particular, firstly, media reports can effectively reduce the cost of information collection of small and medium investors, which will help to expand the spreading scope of existing information, increase the proportion of informed transactions. High informed trading ratio will increase the pricing efficiency of the stock market, thus having a positive impact on the stock price information content (Dyck and Zingales [9]). Secondly, the pressure of public opinion generated by media reports helps to improve investor protection and corporate governance, and reduce the probability of external investors being attacked by insiders (Dyck, et al. [10]). Increased investor protection levels give 
investors more willingness and motivation to collect and analyze firm-level information, to engage in investment arbitrage activities, and thus contribute to the improvement of stock information content (Ferreira and Laux [11]). Thirdly, in addition to expanding the scope of information dissemination, the press can also encapsulate existing information and create new information by itself, which can improve the transparency and accounting quality of the company (Fang and Peress [12]; Bushee, et al. [13]). The improvement of transparency and accounting quality can help to improve the information content of stock price (Jin and Myers [14]). However, investors are not completely rational, as Barber and Odean [4] have argued that the reason why media reports have an impact on investor behavior is that they have attracted the attention of investors rather than providing useful information, that's the media reports may manufacture transactions noise rather than increase the information content of stock prices. In addition, whether media reports can improve the stock price information content depends on the authenticity and reliability of the media itself.

The study of media attention and the stock information has appeared in the past two years, and the conclusions are not consistent. Luo J. H. and Cai D. [2] use annual data from 2003 to 2011 of A-share listed companies to analyze the relationship between media reports and the information content of A-share listed companies in China. The results show that the listed companies received more media attention, the information content which measured by 1-R2 is higher. Media coverage has improved the efficiency of China's stock market by providing information to the investors and limiting the information asymmetry of the capital market. Li Y. Z. and Xu Q. F. [3] used the 115 companies included in "Chinese Listed Companies Public Opinion List" in 2012 as samples, conducted empirical analysis of the amount of negative media reports, network search volume and informativeness of stock. It turned out that during the negative public opinion period, the more network media reports, the larger network search volume and the more frequently transaction of institutional investors, contribute to improve the stock price information content. Yang J., et al. [7] used Baidu search engine to analyze the relationship between the number of news reports and the heterogeneous volatility of stock price measured by 1-R2, and the influence of institutional investors on this relationship. The results show that there is a significant " $U$ " effect between the number of media reports and heterogeneous volatility, and with institutional shareholding ratio increasing, the above "U" type relationship will weaken.

Based on the above analysis, we find that most of the literatures about the media attention and the stock price information content in China have selected the A-share market as the research sample, and the conclusions are not the same. GEM, which enjoys high-growth and mainly serves high-tech innovative SMEs, whose trading rules, investor structure, market liquidity and other aspects have much significant difference from the motherboard market. Whether the press can enhance GEM stock price information content still remains to be further empirically tested. On the basis of the above analysis, in view of the individual 
investors are the majority in GEM, who are more susceptible to the impact of news media, therefore, this paper puts forward the first hypothesis:

$\mathrm{H} 1$ : The increase in media attention is conducive to the improvement of stock information content.

Stock liquidity refers to the ability of stock trading quickly at a reasonable price, which is the embodiment of capital market vitality. At present, during the study of stock liquidity and price information content, most of foreign scholars affirmed the positive correlation between the two. The theoretical model of Holmstrom and Tirole [15] suggests that with the rapid flow of stocks, the marginal information value of public information decreases rapidly, the marginal value of private information increases, and private information may get excess Earnings, thus making uninformed investors are willing to pay to the informed trader to obtain the appropriate private information, which encourage investors to collect information, making the company characteristics go into the stock price, result in increasing the price information content. Chung and Hrazdil [16] used high-frequency data, found that when the liquidity of stock is higher, the shocks on the stock price caused by investors are smaller, making it possible to do information arbitrage. Informed traders will buy from non-informed traders at low cost and then sell at high prices to gain the proceeds, promoting informed traders to collect information, making the company information reflected in the stock price. Edman [17] found that when the marginal cost of information collection is less than the marginal value of information, investors have the power to collect information. In the fast-moving securities market, the marginal cost of information collection is very low, and investors have impetus to collect the characteristics information of the subject, leading to the company's stock information content increased.

There are few literatures on the study of stock liquidity and stock price information in China, and the research conclusions are slightly different. Chen M. G. and Mao X. Y. [18] believe that investors have higher enthusiasm for stocks with higher information content, and stocks with higher stock price information content appear higher liquidity. Su D. W. and Xiong J. C. [19] used stock price information as the intermediate variable in the study of the relationship of stock liquidity and CEO compensation stock sensitivity, and their empirical studies show that stock liquidity can help investors to dig the characteristics of company-level information. That's listed companies can improve the stock liquidity to promote the information content of stock prices rise, thereby increasing the sensitivity of the pay of CEO. Kong D. M., et al. [20] argue that, in a highly liquid market, the transaction costs of information arbitrage are low, and the arbitrageurs' trading behavior leads to information access to stock prices, improving stock pricing efficiency, which is also called improvement of information content. Gu N. K. and Chen H. [21] have examined the relationship between stock liquidity and stock price information, and found that with the speed of stock liquidity the difficulty of obtaining private information is increasing, and the marginal value of information arbitrage is declining, while the cost is rising. So 
in the initial stage, the information content of stock increases with the acceleration of stock liquidity until the marginal benefit of information arbitrage equals the marginal cost, and then decreases with the increase of stock liquidity. And it turns out ultimately inverted U-shaped relationship.

Based on the above analysis, this paper presents the second hypothesis:

$\mathrm{H} 2$ : The acceleration of stock liquidity is conducive to the improvement of stock information content.

In general, the high-liquidity stocks are more popular to information arbitrage investors, and arbitrageurs affect the stock price information content in the realization of effective information arbitrage process (Du H. T. [22]). The press is more concerned about the stocks with fast liquidity, so the relationship between the amount of media reports and its stock price information content will also be affected by the liquidity of the stock. Use Kong D. M., et al. [20] for reference, in whose study of institutional investors, liquidity and stock price information content, using the interaction variables of institutional investors and liquidity, put the media news reporting data, stock liquidity index and the cross of the two items in the model at the same time, to study the relationship between stock liquidity and media news attention and the effect of stock liquidity on this relationship. Since the higher liquidity stocks are more vulnerable to media attention, the logic of the framework in this paper is that stock liquidity accelerating the stock price information content, the number of media news reports is also conducive to the improvement of stock information content. Therefore, this paper speculated that with the acceleration of stock liquidity, the reason why media reports promote the price of information content is likely that the media pays close attention to the stocks with prominent liquidity, that is, stock liquidity is likely to weaken the acceleration the media attention on stock price information. And the third hypothesis of this paper is put forward:

H3: With the acceleration of the liquidity level, the increase of media news attention reduces the increase of stock price information content.

\section{Research Design}

\subsection{Sample Selection and Data Sources}

The total sample is from 2009 to 2015, and the total sample is screened according to the following principles: 1) In view of the speculation atmosphere of new stock market is serious in China's stock market, and investors are keen to "hit the IPO" resulting in the returns rate of new stock frequently fluctuate. So in the annual sample, we eliminate companies listed less than one year. 2) According to the stock information content calculation method, we exclude companies with less than 30 weekly yielding rates. 3) Eliminate samples with missing data of corporate governance or financial data. 4) Taking into account the measurement of news coverage data, the number of companies with more than 100000 media articles or less than 10 media articles is excluded from the annual data. After the above four-fold screening, we got the final 1310 valid samples. The annual distribution of the samples is as Table 1, and industry distribution is presented in 
Table 2.

The data used in this paper, except that the amount of media news is collected by hand, all the other data is from CSMAR $^{1}$ database and WIND ${ }^{2}$ database. Stock weekly yield $\left(r_{i}\right)$, weekly trading value $\left(\right.$ Valtrd $\left._{i}\right)$ and market circulation value $\left(\right.$ Mvosd $\left._{i t d}\right)$ are from the CSMAR database. Asset size ( Size ), institutional shareholding ratio (Ins), shareholding ratio of the largest shareholder (Top1), return on total assets ( Roa ), industry ( Industry), listed years ( Age ), return on equity ( Roe ) are from the WIND database.

\subsection{Description and Definitions of Variables}

\subsubsection{Stock Information Content (Syn)}

Morck, Yeung and Yu [1] is the first to decompose the stock return rate into the market-level part and firm-specific part according to the simplified capital asset

Table 1. Annual distribution of samples.

\begin{tabular}{ccccccc}
\hline Year & 2011 & 2012 & 2013 & 2014 & 2015 & Total \\
\hline Capacity & 85 & 219 & 312 & 342 & 352 & 1310 \\
Proportion & $6.49 \%$ & $16.72 \%$ & $23.82 \%$ & $26.11 \%$ & $26.87 \%$ & $100.00 \%$ \\
\hline
\end{tabular}

Table 2. Industry distribution of samples.

\begin{tabular}{ccc}
\hline Industry & Capacity & Proportion \\
\hline Agriculture Industry & 21 & $1.60 \%$ \\
Mining Industry & 17 & $1.30 \%$ \\
Manufacturing Industry & 918 & $70.08 \%$ \\
Electric, Heating, Gas and Water Production \& & 4 & $0.31 \%$ \\
Supply Industry & 18 & $1.37 \%$ \\
Construction Industry & 16 & $1.22 \%$ \\
Wholesale \& Retail Trade & 9 & $0.69 \%$ \\
Transportation, Warehousing \& Postal Service & 217 & $16.56 \%$ \\
Information Transmission, Software \& & 19 & $1.45 \%$ \\
Information Technology Services & 20 & $1.53 \%$ \\
Leasing \& Commerical Service & 17 & $1.30 \%$ \\
Scientific Research \& Technical Services & 10 & $0.76 \%$ \\
Water Resources, Environment \& Public & 24 & $1.83 \%$ \\
Facilities Management & 1310 & $100.00 \%$ \\
Health \& Social Work & & 10 \\
\hline Culture, Sports \& Recreational Services & Total &
\end{tabular}

"CSMAR Financial Database" is developed by Shenzhen Guotai'an Information Technology Co., Ltd., which is developed according to international database standards (CRSP and COMPUSTAT). It is a research-based accurate database for China's financial and economic fields, including stock market, corporate research, fund market, bond market, derivative market, economic research, industry research, overseas research and special research 11 large series, and it has 75 databases.

${ }^{2}$ Wind database is one of the most complete and accurate financial data warehouse with the core of finance and securities data in china. The data covers stocks, funds, bonds, foreign exchange, insurance, futures, financial derivatives, spot trading, macro economy, finance and economics. Furthermore, it can update in the first time to provide real-time information to meet the needs of users. 
pricing model. According to the meaning of the non-synchronous index R2 in capital asset pricing model, we take 1-R2 as the non-synchronous stock price indicators, think that the non-synchronous index of stock price reflects the degree that the stock price contains company's characteristic information, that is, the larger is 1-R2, the more company's characteristic information is, and the higher the stock information content is. The specific approach is:

The yield rate $r_{i t}$ of company $i$ in period $t$ is expressed as:

$$
r_{i t}=\alpha+\beta_{i m} r_{m t}+\varepsilon_{i t} .
$$

$r_{m t}$ refers to the market return rate in period $t$, mainly subject to the amount of market public information. The residuals $\varepsilon_{i t}$ reflects the part company-specific return fluctuations that can't be affected by public information, that is, the effect of company characteristics information on stock returns. The goodness of fit R2 means synchronization degree that stock prices fluctuates with the market average price volatility, so $1-\mathrm{R} 2$ can be used to measure the non-synchronous degree of stock price volatility, that is the proportion of corporate identity information stock price fluctuations reflect. On the individual stocks, the greater the impact of company traits on stock returns, the greater the stock price volatility, that is, the greater $\varepsilon_{i t}$ is, the greater is 1-R2, which also means the greater the stock returns that is affected by the firm-specific information, the greater the stock price information content, and vice versa. This approach has been widely used by many scholars at home and abroad (You J. X., et al. [23]; Chen X. S. [24]).

On the basis of the studies of Morck, Yeung and Yu [1], Chen, et al. [25], Yuan Z. Z. and Ju X. F. [26], Huang J. and Guo Z. R. [27], which show that the fluctuation of stock price in the same industry may be common due to the characteristics of the industry, and the difference of fluctuation between stocks from different industries is larger. In the view of the model information affecting stock fluctuation, the public information may contain the industry information. Separate the industry information from the market public information, which means stock returns, may not only be effected by the market public information and company characteristics information, but also by industry-level information. Then, on the basis of Formula (1), propose:

$$
r_{i j t}=\alpha+\beta_{1 m} r_{m t}+\beta_{2 j} r_{j t}+\varepsilon_{i t} .
$$

Here, $r_{i j t}$ indicates return rate of stock $i$ in $j$ industry of $t$ period. $r_{m t}$ indicates market return rate in $t$ period. $r_{j t}$ indicates return rate of $j$ industry in $t$ period. $\varepsilon_{i t}$ is the residual items. Similar to Equation (1), the goodness of fit R2 in the above regression equation represents the effect of market and industry information on the change of stock return, while stock nonsynchronization index 1-R2 represents the effect of firm characteristic information on stock return.

In order to avoid the lagged effect of market and industry information on stock returns fluctuation. Durnev, et al. [28], Wu W. L. and Zhang Z. [29] proposed to add the lagged market return to the right side of the above model. In 
this paper, for the sake of robustness, we add the first-order lagged term of the market return rate $\left(r_{m t-1}\right)$ and the industry return rate $\left(r_{j t-1}\right)$ in the Formula (2). The model used to calculate the stock non-synchronization index is as follows:

$$
r_{i j t}=\alpha+\beta_{1 m} r_{m t}+\beta_{2 j} r_{j t}+\beta_{3 m} r_{m t-1}+\beta_{4 j} r_{j t-1}+\varepsilon_{i t} .
$$

It should be noted that the stock returns used in this paper is the weekly return rate that have considered the reinvestment of cash dividend, the market rate of return and industry earnings are calculated by the weekly return rate according to the weighted average market capitalization. $r_{i j t}$ is the weekly return rate of stock $i$ in $j$ industry $t$ week, $r_{m t}$ is the market return rate in $t$ week, $r_{m t-1}$ is the market return rate in $t-1$ week, $r_{j t}$ is the industry return in $t$ week, $r_{j t-1}$ is the industry return rate in the $t-1$ week, $\varepsilon_{i t}$ is the residual term.

From the regression Equation (3), we can get the goodness of fit R2. In view of the value of $\mathrm{R} 2$ lies between 0 and 1, so the non-synchronous stock price index 1-R2 also lays between 0 and 1, which does not meet the normal distribution requirements in ordinary least squares regression, so we conduct the logarithmic conversion and the definition of non-synchronous stock price index is:

$$
\text { Syn }=\operatorname{Ln}\left[\left(1-R^{2}\right) / R^{2}\right] \text {. }
$$

\subsubsection{Media Attention ( $L$ n Media)}

There is no uniform approach to the measurement of media attention in the current literature. In this paper, we take the methods of Rao Y. L. and Wang P. [30], Luo J. H. and Cai D. [2], Huang J. and Guo Z. R. [27] and Yang J., et al. [7] for reference. Specifically, use Baidu news advanced search, to search the articles with titles contain the company's stock abbreviation in each sample year. After entering the abbreviation of the sample company and selecting the query period, the Baidu news search will automatically output the number of news coverage of the range. After access to the company's annual number of media news reports, take natural logarithmic of the sum of Media plus 1 to measure the level of the company's annual news media coverage, that's $L \mathrm{n} M$ edia $=\operatorname{Ln}($ Media +1$)$. As to the companies with ambiguous stock abbreviation, or the stock abbreviation repeats with daily term, we use the stock abbreviation and the stock code to conduct the search. As to the stocks whose abbreviation is changed, we search using the old name before the name changed year, and after the name changed year, search using the old name. As to the renamed year, according to the dividing point of announcement the company changed the name, use the old name before the date of the announcement, and use the new name after the announcement date. And then sum them up as the index of media attention.

\subsubsection{Stock Liquidity (Tover)}

On the selection of stock liquidity index, this paper learns from the previous studies, and uses the average daily turnover rate within the year to measure stock liquidity:

$$
\text { Tover }_{i t}=\frac{1}{D_{i t}} \sum_{D=1}^{D_{i t}}\left(\frac{\text { Valtrd }_{i d t}}{\text { Mvosd }_{i d t}}\right) .
$$


Valtrd $_{i t d}$ is the transaction amount of stock $i$ in $d$ week $t$ year. Mvosd $_{\mathrm{itd}}$ is the circulation market value of stock $i$ in $d$ week $t$ year. $D_{\mathrm{it}}$ is the total number of trading weeks.

\subsubsection{Control Variables}

According to the related literatures, this paper select the following control variables: the size of the company ( Size ), the proportion of institutional ownership (Ins), the proportion of the largest shareholder (Top1), financial leverage ( Lev), asset-liability ratio (ROA), Industry and Year.

\section{1) Enterprise size ( Size)}

This paper selects the total assets at the end of the year as the proxy variable of firm size. In general, the larger the company, the more famous the brand, and the company will be more susceptible to the extensive concern of investors. Investors have greater motivation to do information arbitrage, and the stock price information is the more.

2) Institutional shareholding ratio ( Ins )

The institutional shareholding ratio used in the paper refers to the proportion of the number of shares held by institutional investors, including funds, brokerage firms, brokerage products, QFII, insurance companies, social security funds, trust companies, finance companies, banks, the sun private, general corporate and non-financial listed companies. The institutional shareholding index used in the paper is directly from the WIND database.

A large number research shows that institutional investors because of its advantages in the information collection and information processing, the number of shares and trading activities are closely linked with individual stocks excess returns and price efficiency. Generally speaking, the institutional shareholding promotes the market information efficiency.

3) The largest shareholder ratio ( Top1)

The proportion of the largest shareholder ( Top1) reflects the concentration of ownership. Generally speaking, the motivation for investors to collect information depends on the amount of their holdings, and shareholders with large holdings are more likely to collect information for arbitrage.

4) Financial Leverage ( $L e v$ )

Select the asset-liability ratio ( $L e v$ ) that is the ratio of total debt to total assets at the end of year to measure financial leverage.

5) Return on Total Assets (ROA)

Return on total assets (ROA) measures the overall profitability of an enterprise.

6) Industry ( Industry ), year ( Year ) and dummy variable

The industry variable is classified according to the Guidelines for Industry Classification of Listed Companies (2012 Revision) issued by China Securities Regulatory Commission. This paper controls two types of dummy variables: industry classification variable (Industry) and annual variable (Year ). The variables used in the paper are shown in Table 3. 


\subsection{Model Design}

For the three sets of assumptions proposed above, the following three models were designed:

$$
\begin{gathered}
\operatorname{Syn}_{i t}=\beta_{0}+\beta_{1} \text { LnMedia }_{i t}+\sum \beta_{j} \text { Control }_{i t}+\text { Industry }+ \text { Year }+\varepsilon_{i t} . \\
\text { Syn }_{i t}=\beta_{0}+\beta_{1} \text { LnMedia }_{i t}+\beta_{2} \text { Tover }_{i t}+\sum \beta_{j} \text { Control }_{i t}+\text { Industry }+ \text { Year }+\varepsilon_{i t} . \\
\text { Syn }_{i t}=\beta_{0}+\beta_{1} \text { LnMedia }_{i t}+\beta_{2} \text { Tover }_{i t}+\beta_{3} \text { Tover }_{i t} \text { Media }_{i t} \\
+\sum \beta_{j} \text { Control }_{i t}+\text { Industry }+ \text { Year }+\varepsilon_{i t} .
\end{gathered}
$$

Equation (6) examines the relationship between media attention (LnMedia) and stock price information (Syn) to verify hypothesis H1. Equation (7) validates the relationship between stock liquidity ( Tover ) and stock price information ( Syn ). Equation (8) is used to investigate the modulation effect of stock liquidity (Tover) on the relationship between media attention (LnMedia) and stock price information ( Syn ). We get Equation (8) on the basis of the Equation (6) added the cross term of media attention and stock liquidity to verify hypothesis $\mathrm{H} 3$.

\section{Empirical Analysis}

\subsection{Descriptive Statistics}

Table 4 shows the descriptive statistical analysis of the main variables in this study. Among them, the mean of R2 is 0.483 , the median is 0.490 , the standard deviation is 0.176 , which is slightly higher than the statistical result from the studies of Luo J. H. and Cai D. [2], Yang J., et al. [7] on China's main market. This difference shows that stock price synchronization in China's GEM is slightly higher than the overall level of China's capital market. Since there is no

\begin{tabular}{|c|c|c|}
\hline $\begin{array}{l}\text { Types of } \\
\text { variables }\end{array}$ & Variable symbol & Variable declaration \\
\hline $\begin{array}{l}\text { Explained } \\
\text { Variable }\end{array}$ & Syn & $\begin{array}{l}\text { The value of the stock non-synchronization, equals to } \\
\text { the transformation of value of the goodness-of-fit } \\
\text { obtained from the regression model (3) }\end{array}$ \\
\hline Explanatory & LnMedia & $\begin{array}{l}\text { Media attention, equals to the natural logarithm of the } \\
\text { number of news articles plus } 1\end{array}$ \\
\hline Variable & Tover & $\begin{array}{l}\text { Turnover rate, equals to the average daily turnover rate } \\
\text { within the year }\end{array}$ \\
\hline \multirow{7}{*}{$\begin{array}{l}\text { Control Vari- } \\
\text { able }\end{array}$} & Size & Company size, equals to the total assets at the end of year \\
\hline & Ins & Shareholding Ratio of Institutional \\
\hline & Top1 & Shareholding ratio of the largest shareholder \\
\hline & Lev & Debt-to-assets ratio \\
\hline & Roa & Return On Assets \\
\hline & Industry & Industry Dummy \\
\hline & Year & Year Dummy \\
\hline
\end{tabular}
special research on the GEM so far, this paper does not do comparison about GEM. The mean value of the stock non-synchronization index Syn is 0.227,

Table 3. Variable definitions and descriptions. 
Table 4. Descriptive statistics.

\begin{tabular}{cccccccc}
\hline stats & $\mathrm{N}$ & $\min$ & mean & $\max$ & $\mathrm{p} 50$ & $\mathrm{p} 25$ & $\mathrm{sd}$ \\
\hline R2 & 1310 & 0.001 & 0.483 & 0.980 & 0.490 & 0.360 & 0.176 \\
Syn & 1310 & -2.372 & 0.227 & 5.249 & 0.153 & -0.306 & 0.781 \\
Media & 1310 & 24.000 & 2058.196 & 284000.000 & 1140.000 & 866.000 & 10359.577 \\
LnMedia & 1310 & 3.219 & 7.124 & 12.557 & 7.040 & 6.765 & 0.713 \\
Tover & 1310 & 0.026 & 0.193 & 0.700 & 0.168 & 0.107 & 0.111 \\
Size & 1310 & 266.121 & 1880.408 & 23733.477 & 1333.923 & 915.664 & 1792.556 \\
Ins & 1310 & 0.001 & 27.586 & 151.474 & 22.779 & 9.889 & 21.194 \\
Top1 & 1310 & 4.380 & 31.922 & 69.360 & 29.990 & 22.460 & 12.641 \\
Lev & 1310 & 1.105 & 26.233 & 88.643 & 23.300 & 13.739 & 16.040 \\
Roa & 1310 & -45.381 & 6.182 & 31.763 & 5.966 & 3.131 & 5.684 \\
\hline
\end{tabular}

the median is 0.153 , and the standard deviation is 0.781 . There is a certain gap between the companies. The statistical results of media attention show that the average annual number of news report about GEM listed companies is 2058, an average of 5.6 every day, and this results were significantly higher than similar studies on the A-share market statistics, which reflects media's preference for the GEM Market from the side point. The average of annual average stock turnover is $19.3 \%$ in GEM, and the average shareholding ratio of institutional investors is $27.59 \%$.

\subsection{Regression Analysis}

\subsubsection{Number of Media News Reports and the Information Content of Stock Price}

The Model (6) column in Table 5 reports the regression results for the relationship between the number of media news stories (LnMedia) and the stock price information ( Syn ).

According to the result of regression, when uses stock price non-synchronization index Syn as the proxy variable of stock information content, the media attention variable $\mathrm{LnMedia}$ is positively correlated with stock price information content at the $1 \%$ significance level, that is, the more news media reports, the higher the stock price information content. This result is consistent with the results of Huang J. and Guo Z. R. [27], Luo J. H. and Cai D. [2]. This result confirms the hypothesis $\mathrm{H} 1$, and affirms the effectiveness of the news media in promoting market information efficiency to a certain extent. That is the increased number of news reports about GEM listed companies, which effectively promotes the company's quality information into the stock price, thereby, enhancing the listed company's stock price information content.

The regression analysis of control variables show that institutional ownership ( Ins ) is positively correlated with stock price information ( Syn ), but this result is not statistically significant, suggesting that institutional investors of GEM do not play their professional advantage in information mining and information processing. The proportion of shareholding of the largest shareholder Top1 is 
Table 5. Regression analysis results of Model (9).

\begin{tabular}{|c|c|c|}
\hline \multirow{2}{*}{ Variables } & \multicolumn{2}{|c|}{ Model (9) } \\
\hline & Syn & LnMedia \\
\hline \multirow[t]{2}{*}{ LnMedia } & $0.324^{* *}$ & \\
\hline & $(-2.29)$ & \\
\hline \multirow[t]{2}{*}{ Syn } & & $0.952^{\star * *}$ \\
\hline & & $(-5.67)$ \\
\hline \multirow[t]{2}{*}{ Tover } & $0.584^{* * *}$ & \\
\hline & $(-3.29)$ & \\
\hline \multirow[t]{2}{*}{ Size } & $0.0000252^{* * *}$ & \\
\hline & $(-2.72)$ & \\
\hline \multirow[t]{2}{*}{ Ins } & $0.00262^{\star * *}$ & \\
\hline & $(-3.14)$ & \\
\hline \multirow[t]{2}{*}{ Top1 } & 0.001 & \\
\hline & $(-1.31)$ & \\
\hline \multirow[t]{2}{*}{$L e v$} & $0.003^{* * *}$ & \\
\hline & $(-3.03)$ & \\
\hline \multirow[t]{2}{*}{ Roa } & $0.009^{* * *}$ & \\
\hline & $(-3)$ & \\
\hline \multirow[t]{2}{*}{ Age } & & $0.084^{\star * *}$ \\
\hline & & $(-3.78)$ \\
\hline \multirow[t]{2}{*}{$\mid R$ oe $\mid$} & & $0.008^{\star * *}$ \\
\hline & & $(-3.34)$ \\
\hline \multirow[t]{2}{*}{$R-$ var } & & $12.730^{* * *}$ \\
\hline & & $(-2.67)$ \\
\hline \multirow[t]{2}{*}{ Develop } & & $0.002^{*}$ \\
\hline & & $(-1.69)$ \\
\hline \multirow[t]{2}{*}{ Constant Term } & $-2.480^{* * *}$ & $6.127^{* * *}$ \\
\hline & $(-2.89)$ & $(-26.21)$ \\
\hline Industry & Controlled & Controlled \\
\hline Year & Controlled & Controlled \\
\hline Sample Capacity & 1310 & 1310 \\
\hline
\end{tabular}

$t$ statistics in parentheses ${ }^{*} \mathrm{p}<0.1,{ }^{* *} \mathrm{p}<0.05,{ }^{* * *} \mathrm{p}<0.01$.

positively correlated with the information content of stock price at the significance level of $5 \%$, which indicates that the ownership concentration is beneficial to the improvement of the information content of stock price. Company size (Size) is positively correlated with stock price information, which is consistent with the conclusion of Wu W. L. and Zheng Z. [29]. The asset-liability ratio (ROA) and return on assets (ROI) are both positively correlated with the information content of the stock price and have a certain significance level, which are consistent with the conclusions of Huang J. and Guo Z. R. [27]. 


\subsubsection{Stock Liquidity and Price Information Content}

The Model (7) column in Table 5 reports the regression result for the relationship between stock liquidity (Tover) and stock price information (Syn ). According to the result, when the stock price non-synchronous index Syn is taken as the proxy variable of stock price information, the stock exchange rate (Tover) is positively correlated with the price information content at the $1 \%$ significance level, that is, the stock turnover rate is faster, the higher the information content. This result is consistent with the views of Chen M. G. and Mao X. Y. [18], Kong D. M., et al. [20], Su D. W. and Xiong J. C. [19], which confirms the hypothesis $\mathrm{H} 2$.

\subsubsection{The Regulating Effect of Stock Liquidity on the Relationship between the Number of Media News Reports and the Price of Information}

The Model (8) column in Table 5 reports the result of the regression of stock liquidity (Tover) on the relationship between the number of media news stories (LnMedia) and stock price information (Syn). According to the result, the coefficient of average annual turnover (Tover) is significantly positive at $1 \%$ significance level after adding the annual turnover rate (Tover) and interaction term ( LnMedia*Tover) on the basis of Model (6), which once again proves the hypothesis that the stock liquidity is conducive to promoting the stock price information content. It is worth noting that the coefficient of the cross term of average annual turnover rate and the media concern ( LnMedia*Tover) is significant negative at the 5\% significance level, indicating that the acceleration of stock liquidity will reduce the positive impact of media attention on the stock price to a certain extent. This may be due to the fact that, when the stock trading is accelerated, the investor is active, and the acceptance of media news about analysis of the company's characteristics is weakened. This may also because when the market liquidity accelerates, the media's press release is active, and there may appear contradictory information, or even differences in news coverage will also give ordinary investors obstacles to identify information and make an investment decision. Either way, there needs further research to explain why the acceleration of stock liquidity reduces the positive impact of media attention on stock price information.

\subsection{Robustness Test}

In view of Luo J. H. and Cai D. [2] mentioned that, there may exist endogenous problems in the study of the number of media news reports and stock price information content. That is the positive relationship between the media attention and price information content does not necessarily mean that the number of media news reports has contributed to the improvement of the information content of stock price. It may also be because the stock with high stock price information can arouse more media suspicion. This paper draw lessons from Luo J. H. and Cai D. [2], propose the following simultaneous equation model for robustness testing: 


$$
\begin{gathered}
\text { Syn }_{i t}=\beta_{0}+\beta_{1} \text { LnMedia }_{i t}+\beta_{2} \text { Tover }_{i t}+\sum \beta_{j} \text { Control }_{i t}+\text { Industry }+ \text { Year }+\varepsilon_{i t} . \\
\text { LnMedia }_{i t}=\beta_{0}+\beta_{1} \text { Syn }_{i t}+\beta_{2} \text { Age }_{i t}+\beta_{3} \mid R \text { oe }_{i t} \mid+\beta_{4} R-\operatorname{var}_{i t} \\
+\beta_{5} \text { Develop }_{i t}+\text { Industry }+ \text { Year }+\varepsilon_{i t} .
\end{gathered}
$$

In the simultaneous equation model (9), the variables that affect the stock price information ( Syn ) are consistent with the regression model above, and the variables that affect the number of media news reports ( $L \mathrm{n} M$ edia ) except for the stock price information ( Syn), taking into account the usual situations. The companies with longer the time to go public, the better or worse the operating results, the more obvious stock price fluctuates, the higher the development of regional media, will be more vulnerable to the media's favor. So we add the company listing time (Age), the absolute value of return net assets ( $\mid R$ oe $\mid$ ), the variance of the weekly return on stocks ( $R$-var ), and the media development index ( Develop ) of the province in which the company is located. In addition, the dummy variables of company's industry (Industry) and annual (Year) are controlled. It is worth noting that the media development index (Develop) is used as an instrumental variable of the number of media reports ( $L$ nMedia) derived from Media Development Indices by Province by Yu G M [31]. The other variables are defined in Table 1 above.

Regression analysis of the model (9) was performed in Table 5.

It can be seen that, after controlling for the endogeneity between the number of news media reports ( $L \mathrm{nMedia}{ }_{i t}$ ) and the price information content ( Syn ), the coefficient of is still significantly positive at the $5 \%$ significance level, demonstrating that the news media report significantly increases stock price information once again, which proves the conclusion obtained in this paper is robust.

\section{Conclusions and Implication}

With the popularity of mobile internet, the development of information age, the so-called "information explosion" is more and more obvious. The press contacts more closely with people's production and living. In this case, the importance of the news media is self-evident. The GEM is favored by many news media because of its high liquidity and high risk. In addition, the investors of GEM are mainly small and medium investors who have obstacles in information gathering and information processing, and they tend to get investment information from the news media. Obviously, if the news media reports can provide useful information about the listed companies, it will help investors make more reasonable investment decisions so as to enhance the market information efficiency and promote the information content of the stock price. Based on this, this article uses "Baidu News" advanced search to search articles with titles containing the name of the sample, and uses the number of articles to measure media attention, uses non-synchronous stock price index to measure the information content of stock prices and empirically analyzes the effect of media attention on stock price information. It turns out that the quantity of media news reports and the stock liquidity are positively correlated with the information content of stock price, 
that is, the information content of stock price increases with the increase of the number of media news reports and the acceleration of stock liquidity. This conclusion is still significant after eliminating endogenous. Further study found that stock liquidity weakened the promotion role of the media attention on the stock information content. This interesting conclusion may be due to that, when stock liquidity accelerates, since the market is active, investors' analytical judgment about the characteristic information is vulnerable to the impact of market liquidity, whose acceptability of media news reports will be weakened to a certain extent, which may reduce the positive effect of media attention on the information content of stock price. It may be because when the market liquidity increases, the press is also active, various news contents may appear and different news reports will make it difficult for ordinary investors to identify information and make investment decision. They need further analysis to identify the specific reason.

The conclusions of this paper have the following theoretical and policy significance: Academically, the result that there exists positive relationship between media attention and the price information content in GEM, perfects information environmental governance theory in China's GEM, and provides theoretical support for exploring the effectiveness of China's capital market. Practically, there are three aspects. First, the promoting role of media news reporting in the information content of stock prices, clarifies the role of external supervision in China's capital market, and provides empirical evidence for regulators to give full play to the role of information disclosure. Second, for the investors, the result of this paper is helpful to guide investors to make better use of the media reports to make investment decisions and alleviate the information asymmetry in the capital market. Third, the listed companies can make full use of the media's information dissemination function so as to make more company characteristics information into the company's stock price, which can make the stock price close to the company's intrinsic value and can improve the financing efficiency of listed companies.

However, due to the availability of data and other related technical reasons, this paper has some limitations. For example, the media attention is measured by the number of manually searched news articles, and there is no breakdown of the types of news media and news content; the accuracy of the data may be a problem. In addition, because of the simple operation and the availability of data, this paper uses stock price non-synchronization index as a proxy variable of the information content of stock price; the accuracy of this index is questioned. For these limitations, further research needs to be further improved.

\section{References}

[1] Morck, R., Yeung, B. and Yu, W. (2000) The Information Content of Stock Markets: Why Do Emerging Markets Have Synchronous Stock Price Movements? Journal of Financial Economics, 58, 215-260.

[2] Luo, J.H. and Cai, D. (2013) Can Media Reports Improve the Information Content of the Stock? Investment Research, 32, 38-53. 
[3] Lee, Y.Z. and Xu, Q.F. (2015) Research of Stock Information Content Based on the Negative Public Opinion Network Events. Friends of Accounting, 10, 104-110.

[4] Barber, B.M. and Odean, T. (2008) All That Glitters: The Effect of Attention and News on the Buying Behavior of Individual and Institutional Investors. Review of Financial Studies, 21, 785-818.

[5] Zhang, Y.H., Wan, D.F. and Fu, L.M. (2011) The Media Effect of Stock Returns: Risk Compensation or Excessive Attention to Vulnerable. Financial Research, 8, 143-156.

[6] Rao, Y.L., Peng, D.F. and Cheng, D.C. (2010) Can Media Attention Cause Abnormal Stock Returns?-Evidence from Chinese Stock Market. Systems Engineering Theory and Practice, 30, 287-297.

[7] Yang, J., Zhan, W.J. and Liu, R.Z. (2015) Research of Stock Price Volatility Based on the Heterogeneity Information of Media Reports. Proceedings of the 15th National Information Technology and Computer Simulation Conference, Changsha, 15 June 2015, 1-13.

[8] Tan, S.T., Cui, X.Y. and Sun, Y.M. (2014) Media Reports, Institutional Trading and Stock Price Volatility. Journal of Financial Research, 3, 180-193.

[9] Dyck, A. and Zingales, L. (2004) Control Premiums and the Effectiveness of Corporate Governance Systems. Journal of Applied Corporate Finance, 16, 51-72.

[10] Dyck, A., Volchkova, N. and Zingales, L. (2007) The Corporate Governance Role of the Media: Evidence from Russia. NBER Working Paper No. 12525.

[11] Ferreira, M.A. and Laux, P.A. (2007) Corporate Governance, Idiosyncratic Risk, and Information Flow. Journal of Finance, 62, 951-989.

https://doi.org/10.1111/j.1540-6261.2007.01228.x

[12] Fang, L.H., Peress, J. and Zheng, L. (2014) Does Media Coverage of Stocks Affect Mutual Funds' Trading and Performance? Review of Financial Studies, 27, 3441 3466. https://doi.org/10.1093/rfs/hhu056

[13] Bushee, B.J., Core, J.E., Guay, W., et al. (2010) The Role of the Business Press as an Information Intermediary. Journal of Accounting Research, 48, 1-19. https://doi.org/10.1111/j.1475-679X.2009.00357.x

[14] Li, J. and Myers, S.C. (2006) $\mathrm{R}^{2}$ around the World: New Theory and New Tests. Journal of Financial Economics, 79, 257-292. https://doi.org/10.1016/j.jfineco.2004.11.003

[15] Holmström, B. and Tirole, J. (1993) Market Liquidity and Performance Monitoring. Journal of Political Economy, 101, 678-709. https://doi.org/10.1086/261893

[16] Chung, D.Y. and Hrazdil, K. (2010) Liquidity and Market Efficiency: Analysis of NASDAQ Firms. Global Finance Journal, 21, 262-274. https://doi.org/10.1016/j.gfj.2010.09.004

[17] Edmans, A. (2010) Does the Stock Market Fully Value Intangibles? Employee Satisfaction and Equity Prices. Journal of Financial Economics, 101, 621-640. https://doi.org/10.1016/j.jfineco.2011.03.021

[18] Chen, M.G. and Mao, X.Y. (2007) Shares Information Content and the Level of Market Transaction Activity. Financial Research, 3, 125-139.

[19] Su, D.W. and Xiong, J.C. (2013) Stock Liquidity, Stock Information, Content and CEO Salary Contracts. Economic Research, 11, 56-70.

[20] Kong, D.M., Kong, G.W. and Liu, S.S. (2015) Institutional Investors, Liquidity and Efficiency of Information. Management Science, 18, 1-15.

[21] Gu, N.K. and Chen, H. (2010) Stock Liquidity, Stock Information Content and 
Business Investment Decisions. Management Science, 23, 88-97.

[22] Du, H.T. (2002) Measurement of the Liquidity Risk of Chinese Stock Market. Securities Market Herald, 11, 38-43.

[23] You, J.X., Zhang, J.S. and Jiang, W. (2006) Institution Building, Idiosyncratic Iynchronization Information and the Volatility of Stock Price-Studies Based on $\mathrm{R}^{2}$. Economics, 6, 189-206.

[24] Chen, X.S. (2016) Cross-Listing, Information Environment and the Shanghai and Shenzhen A-Share Market Liquidity. Technology of Zhongnan University, 1, 96106.

[25] Chen, Q., Goldstein, I. and Jiang, W. (2006) Price Informativeness and Investment Sensitivity to Stock Prices. Review of Financial Studies, 20, 619-650. https://doi.org/10.1093/rfs/hhl024

[26] Yuan, Z.Z. and Ju, X.F. (2009) Institutional Environment, Corporate Governance and Share Price Information Content. Management Science, 22, 17-29.

[27] Huang, J. and Guo, Z.R. (2014) News Media Reports and Capital Market Pricing Efficiency-Analysis Based on the Synchronization of Stock Price. Management World, 5, 121-130.

[28] Durnev, A., Morck, R. and Yeung, B.Y. (2003) Value Enhancing Capital Budgeting and Firm-Specific Stock Returns Variation. Social Science Electronic Publishing, 59, 65-105.

[29] Wu, W.L., Zhang, Z. and Peng, Y.L. (2015) Analysts Features, State of the Market and Share Price Information Content. Economy and Management Review, 4, 135147.

[30] Rao, Y.L. and Wang, P. (2010) Effect of Media Attention on the Performance of New Shares-Evidence from Chinese Stock Market. Accounting and Finance, 3, 17.

[31] Yu, G.M. (2012) Chinese Media Development Index Report (2012). People's Daily Publishing House, Beijing. 
Annex

\begin{tabular}{|c|c|c|c|c|c|c|c|c|c|}
\hline \multicolumn{10}{|c|}{ The list of the sample companies } \\
\hline year & stkcd & year & stkcd & year & stkcd & year & stkcd & year & stkcd \\
\hline 2011 & 300001 & 2012 & 300001 & 2013 & 300001 & 2014 & 300001 & 2015 & 300001 \\
\hline 2011 & 300002 & 2012 & 300002 & 2013 & 300002 & 2014 & 300002 & 2015 & 300002 \\
\hline 2011 & 300003 & 2012 & 300003 & 2013 & 300003 & 2014 & 300003 & 2015 & 300003 \\
\hline 2011 & 300004 & 2012 & 300004 & 2013 & 300004 & 2014 & 300004 & 2015 & 300004 \\
\hline 2011 & 300005 & 2012 & 300005 & 2013 & 300005 & 2014 & 300005 & 2015 & 300005 \\
\hline 2011 & 300006 & 2012 & 300006 & 2013 & 300006 & 2014 & 300006 & 2015 & 300006 \\
\hline 2011 & 300007 & 2012 & 300007 & 2013 & 300007 & 2014 & 300007 & 2015 & 300007 \\
\hline 2011 & 300008 & 2012 & 300008 & 2013 & 300008 & 2014 & 300008 & 2015 & 300009 \\
\hline 2011 & 300009 & 2012 & 300009 & 2013 & 300009 & 2014 & 300009 & 2015 & 300010 \\
\hline 2011 & 300010 & 2012 & 300010 & 2013 & 300010 & 2014 & 300010 & 2015 & 300011 \\
\hline 2011 & 300011 & 2012 & 300011 & 2013 & 300011 & 2014 & 300011 & 2015 & 300012 \\
\hline 2011 & 300012 & 2012 & 300012 & 2013 & 300012 & 2014 & 300012 & 2015 & 300013 \\
\hline 2011 & 300013 & 2012 & 300013 & 2013 & 300013 & 2014 & 300013 & 2015 & 300014 \\
\hline 2011 & 300014 & 2012 & 300014 & 2013 & 300014 & 2014 & 300014 & 2015 & 300015 \\
\hline 2011 & 300015 & 2012 & 300015 & 2013 & 300015 & 2014 & 300015 & 2015 & 300016 \\
\hline 2011 & 300016 & 2012 & 300016 & 2013 & 300016 & 2014 & 300016 & 2015 & 300017 \\
\hline 2011 & 300017 & 2012 & 300017 & 2013 & 300017 & 2014 & 300017 & 2015 & 300018 \\
\hline 2011 & 300018 & 2012 & 300018 & 2013 & 300018 & 2014 & 300018 & 2015 & 300019 \\
\hline 2011 & 300019 & 2012 & 300019 & 2013 & 300019 & 2014 & 300019 & 2015 & 300020 \\
\hline 2011 & 300020 & 2012 & 300020 & 2013 & 300020 & 2014 & 300020 & 2015 & 300021 \\
\hline 2011 & 300021 & 2012 & 300021 & 2013 & 300021 & 2014 & 300021 & 2015 & 300022 \\
\hline 2011 & 300022 & 2012 & 300022 & 2013 & 300022 & 2014 & 300022 & 2015 & 300023 \\
\hline 2011 & 300023 & 2012 & 300023 & 2013 & 300023 & 2014 & 300024 & 2015 & 300024 \\
\hline 2011 & 300024 & 2012 & 300024 & 2013 & 300024 & 2014 & 300025 & 2015 & 300026 \\
\hline 2011 & 300025 & 2012 & 300025 & 2013 & 300025 & 2014 & 300026 & 2015 & 300027 \\
\hline 2011 & 300026 & 2012 & 300026 & 2013 & 300026 & 2014 & 300027 & 2015 & 300029 \\
\hline 2011 & 300027 & 2012 & 300027 & 2013 & 300027 & 2014 & 300028 & 2015 & 300031 \\
\hline 2011 & 300028 & 2012 & 300028 & 2013 & 300028 & 2014 & 300029 & 2015 & 300032 \\
\hline 2011 & 300029 & 2012 & 300029 & 2013 & 300029 & 2014 & 300030 & 2015 & 300034 \\
\hline 2011 & 300030 & 2012 & 300030 & 2013 & 300030 & 2014 & 300031 & 2015 & 300035 \\
\hline 2011 & 300031 & 2012 & 300031 & 2013 & 300031 & 2014 & 300032 & 2015 & 300036 \\
\hline 2011 & 300032 & 2012 & 300032 & 2013 & 300032 & 2014 & 300034 & 2015 & 300037 \\
\hline 2011 & 300034 & 2012 & 300034 & 2013 & 300034 & 2014 & 300035 & 2015 & 300038 \\
\hline 2011 & 300035 & 2012 & 300035 & 2013 & 300035 & 2014 & 300036 & 2015 & 300039 \\
\hline 2011 & 300036 & 2012 & 300036 & 2013 & 300036 & 2014 & 300037 & 2015 & 300040 \\
\hline 2011 & 300037 & 2012 & 300037 & 2013 & 300037 & 2014 & 300038 & 2015 & 300041 \\
\hline 2011 & 300038 & 2012 & 300038 & 2013 & 300038 & 2014 & 300039 & 2015 & 300042 \\
\hline 2011 & 300039 & 2012 & 300039 & 2013 & 300039 & 2014 & 300040 & 2015 & 300043 \\
\hline 2011 & 300040 & 2012 & 300040 & 2013 & 300040 & 2014 & 300041 & 2015 & 300044 \\
\hline 2011 & 300041 & 2012 & 300041 & 2013 & 300041 & 2014 & 300042 & 2015 & 300045 \\
\hline 2011 & 300042 & 2012 & 300042 & 2013 & 300042 & 2014 & 300043 & 2015 & 300046 \\
\hline 2011 & 300043 & 2012 & 300043 & 2013 & 300043 & 2014 & 300044 & 2015 & 300047 \\
\hline 2011 & 300044 & 2012 & 300044 & 2013 & 300044 & 2014 & 300045 & 2015 & 300048 \\
\hline
\end{tabular}


Continued

\begin{tabular}{|c|c|c|c|c|c|c|c|c|c|}
\hline 2011 & 300045 & 2012 & 300045 & 2013 & 300045 & 2014 & 300046 & 2015 & 300049 \\
\hline 2011 & 300046 & 2012 & 300046 & 2013 & 300046 & 2014 & 300047 & 2015 & 300050 \\
\hline 2011 & 300047 & 2012 & 300047 & 2013 & 300047 & 2014 & 300048 & 2015 & 300051 \\
\hline 2011 & 300048 & 2012 & 300048 & 2013 & 300048 & 2014 & 300049 & 2015 & 300052 \\
\hline 2011 & 300049 & 2012 & 300049 & 2013 & 300049 & 2014 & 300050 & 2015 & 300053 \\
\hline 2011 & 300050 & 2012 & 300050 & 2013 & 300050 & 2014 & 300051 & 2015 & 300054 \\
\hline 2011 & 300051 & 2012 & 300051 & 2013 & 300051 & 2014 & 300052 & 2015 & 300055 \\
\hline 2011 & 300052 & 2012 & 300052 & 2013 & 300052 & 2014 & 300053 & 2015 & 300056 \\
\hline 2011 & 300053 & 2012 & 300053 & 2013 & 300053 & 2014 & 300054 & 2015 & 300057 \\
\hline 2011 & 300054 & 2012 & 300054 & 2013 & 300054 & 2014 & 300055 & 2015 & 300058 \\
\hline 2011 & 300055 & 2012 & 300055 & 2013 & 300055 & 2014 & 300056 & 2015 & 300059 \\
\hline 2011 & 300056 & 2012 & 300056 & 2013 & 300056 & 2014 & 300057 & 2015 & 300061 \\
\hline 2011 & 300057 & 2012 & 300057 & 2013 & 300057 & 2014 & 300058 & 2015 & 300062 \\
\hline 2011 & 300058 & 2012 & 300058 & 2013 & 300058 & 2014 & 300059 & 2015 & 300063 \\
\hline 2011 & 300059 & 2012 & 300059 & 2013 & 300059 & 2014 & 300061 & 2015 & 300064 \\
\hline 2011 & 300061 & 2012 & 300061 & 2013 & 300061 & 2014 & 300062 & 2015 & 300065 \\
\hline 2011 & 300062 & 2012 & 300062 & 2013 & 300062 & 2014 & 300063 & 2015 & 300066 \\
\hline 2011 & 300063 & 2012 & 300063 & 2013 & 300063 & 2014 & 300064 & 2015 & 300067 \\
\hline 2011 & 300064 & 2012 & 300064 & 2013 & 300064 & 2014 & 300065 & 2015 & 300068 \\
\hline 2011 & 300065 & 2012 & 300065 & 2013 & 300065 & 2014 & 300066 & 2015 & 300069 \\
\hline 2011 & 300066 & 2012 & 300066 & 2013 & 300066 & 2014 & 300067 & 2015 & 300070 \\
\hline 2011 & 300067 & 2012 & 300067 & 2013 & 300067 & 2014 & 300068 & 2015 & 300072 \\
\hline 2011 & 300068 & 2012 & 300068 & 2013 & 300068 & 2014 & 300069 & 2015 & 300073 \\
\hline 2011 & 300069 & 2012 & 300069 & 2013 & 300069 & 2014 & 300070 & 2015 & 300074 \\
\hline 2011 & 300070 & 2012 & 300070 & 2013 & 300070 & 2014 & 300072 & 2015 & 300075 \\
\hline 2011 & 300071 & 2012 & 300071 & 2013 & 300071 & 2014 & 300073 & 2015 & 300076 \\
\hline 2011 & 300072 & 2012 & 300072 & 2013 & 300072 & 2014 & 300074 & 2015 & 300077 \\
\hline 2011 & 300073 & 2012 & 300073 & 2013 & 300073 & 2014 & 300075 & 2015 & 300078 \\
\hline 2011 & 300074 & 2012 & 300074 & 2013 & 300074 & 2014 & 300076 & 2015 & 300079 \\
\hline 2011 & 300075 & 2012 & 300075 & 2013 & 300075 & 2014 & 300077 & 2015 & 300080 \\
\hline 2011 & 300076 & 2012 & 300076 & 2013 & 300076 & 2014 & 300078 & 2015 & 300081 \\
\hline 2011 & 300077 & 2012 & 300077 & 2013 & 300077 & 2014 & 300079 & 2015 & 300082 \\
\hline 2011 & 300078 & 2012 & 300078 & 2013 & 300078 & 2014 & 300080 & 2015 & 300083 \\
\hline 2011 & 300079 & 2012 & 300079 & 2013 & 300079 & 2014 & 300081 & 2015 & 300084 \\
\hline 2011 & 300081 & 2012 & 300080 & 2013 & 300080 & 2014 & 300082 & 2015 & 300085 \\
\hline 2011 & 300082 & 2012 & 300081 & 2013 & 300081 & 2014 & 300083 & 2015 & 300086 \\
\hline 2011 & 300083 & 2012 & 300082 & 2013 & 300082 & 2014 & 300084 & 2015 & 300088 \\
\hline 2011 & 300084 & 2012 & 300083 & 2013 & 300083 & 2014 & 300085 & 2015 & 300089 \\
\hline 2011 & 300085 & 2012 & 300084 & 2013 & 300084 & 2014 & 300086 & 2015 & 300090 \\
\hline 2011 & 300086 & 2012 & 300085 & 2013 & 300085 & 2014 & 300087 & 2015 & 300091 \\
\hline 2011 & 300087 & 2012 & 300086 & 2013 & 300086 & 2014 & 300088 & 2015 & 300092 \\
\hline \multirow[t]{4}{*}{2011} & 300088 & 2012 & 300087 & 2013 & 300087 & 2014 & 300089 & 2015 & 300094 \\
\hline & & 2012 & 300088 & 2013 & 300088 & 2014 & 300090 & 2015 & 300095 \\
\hline & & 2012 & 300089 & 2013 & 300089 & 2014 & 300091 & 2015 & 300096 \\
\hline & & 2012 & 300090 & 2013 & 300090 & 2014 & 300092 & 2015 & 300097 \\
\hline
\end{tabular}




\begin{tabular}{|c|c|c|c|c|c|c|c|}
\hline 2012 & 300091 & 2013 & 300091 & 2014 & 300093 & 2015 & 300098 \\
\hline 2012 & 300092 & 2013 & 300093 & 2014 & 300094 & 2015 & 300099 \\
\hline 2012 & 300093 & 2013 & 300094 & 2014 & 300095 & 2015 & 300100 \\
\hline 2012 & 300094 & 2013 & 300095 & 2014 & 300096 & 2015 & 300101 \\
\hline 2012 & 300095 & 2013 & 300096 & 2014 & 300097 & 2015 & 300102 \\
\hline 2012 & 300096 & 2013 & 300097 & 2014 & 300098 & 2015 & 300103 \\
\hline 2012 & 300097 & 2013 & 300098 & 2014 & 300099 & 2015 & 300104 \\
\hline 2012 & 300098 & 2013 & 300099 & 2014 & 300100 & 2015 & 300105 \\
\hline 2012 & 300099 & 2013 & 300100 & 2014 & 300101 & 2015 & 300106 \\
\hline 2012 & 300100 & 2013 & 300101 & 2014 & 300102 & 2015 & 300107 \\
\hline 2012 & 300101 & 2013 & 300102 & 2014 & 300103 & 2015 & 300108 \\
\hline 2012 & 300102 & 2013 & 300103 & 2014 & 300104 & 2015 & 300109 \\
\hline 2012 & 300103 & 2013 & 300104 & 2014 & 300105 & 2015 & 300110 \\
\hline 2012 & 300104 & 2013 & 300105 & 2014 & 300106 & 2015 & 300111 \\
\hline 2012 & 300105 & 2013 & 300106 & 2014 & 300107 & 2015 & 300112 \\
\hline 2012 & 300106 & 2013 & 300107 & 2014 & 300108 & 2015 & 300113 \\
\hline 2012 & 300107 & 2013 & 300108 & 2014 & 300109 & 2015 & 300114 \\
\hline 2012 & 300108 & 2013 & 300109 & 2014 & 300110 & 2015 & 300115 \\
\hline 2012 & 300109 & 2013 & 300110 & 2014 & 300111 & 2015 & 300116 \\
\hline 2012 & 300110 & 2013 & 300111 & 2014 & 300112 & 2015 & 300117 \\
\hline 2012 & 300111 & 2013 & 300112 & 2014 & 300113 & 2015 & 300118 \\
\hline 2012 & 300113 & 2013 & 300113 & 2014 & 300114 & 2015 & 300119 \\
\hline 2012 & 300114 & 2013 & 300114 & 2014 & 300115 & 2015 & 300120 \\
\hline 2012 & 300115 & 2013 & 300115 & 2014 & 300116 & 2015 & 300121 \\
\hline 2012 & 300116 & 2013 & 300116 & 2014 & 300117 & 2015 & 300122 \\
\hline 2012 & 300117 & 2013 & 300117 & 2014 & 300118 & 2015 & 300124 \\
\hline 2012 & 300118 & 2013 & 300118 & 2014 & 300119 & 2015 & 300125 \\
\hline 2012 & 300119 & 2013 & 300119 & 2014 & 300120 & 2015 & 300126 \\
\hline 2012 & 300120 & 2013 & 300120 & 2014 & 300121 & 2015 & 300127 \\
\hline 2012 & 300121 & 2013 & 300121 & 2014 & 300122 & 2015 & 300128 \\
\hline 2012 & 300122 & 2013 & 300122 & 2014 & 300123 & 2015 & 300129 \\
\hline 2012 & 300123 & 2013 & 300123 & 2014 & 300124 & 2015 & 300130 \\
\hline 2012 & 300124 & 2013 & 300124 & 2014 & 300125 & 2015 & 300132 \\
\hline 2012 & 300125 & 2013 & 300125 & 2014 & 300126 & 2015 & 300133 \\
\hline 2012 & 300126 & 2013 & 300126 & 2014 & 300127 & 2015 & 300135 \\
\hline 2012 & 300127 & 2013 & 300127 & 2014 & 300128 & 2015 & 300136 \\
\hline 2012 & 300128 & 2013 & 300128 & 2014 & 300129 & 2015 & 300137 \\
\hline 2012 & 300129 & 2013 & 300129 & 2014 & 300130 & 2015 & 300138 \\
\hline 2012 & 300130 & 2013 & 300130 & 2014 & 300131 & 2015 & 300139 \\
\hline 2012 & 300131 & 2013 & 300131 & 2014 & 300132 & 2015 & 300140 \\
\hline 2012 & 300132 & 2013 & 300132 & 2014 & 300133 & 2015 & 300141 \\
\hline 2012 & 300133 & 2013 & 300133 & 2014 & 300134 & 2015 & 300142 \\
\hline 2012 & 300134 & 2013 & 300134 & 2014 & 300135 & 2015 & 300143 \\
\hline 2012 & 300135 & 2013 & 300135 & 2014 & 300136 & 2015 & 300144 \\
\hline 2012 & 300136 & 2013 & 300136 & 2014 & 300137 & 2015 & 300145 \\
\hline
\end{tabular}




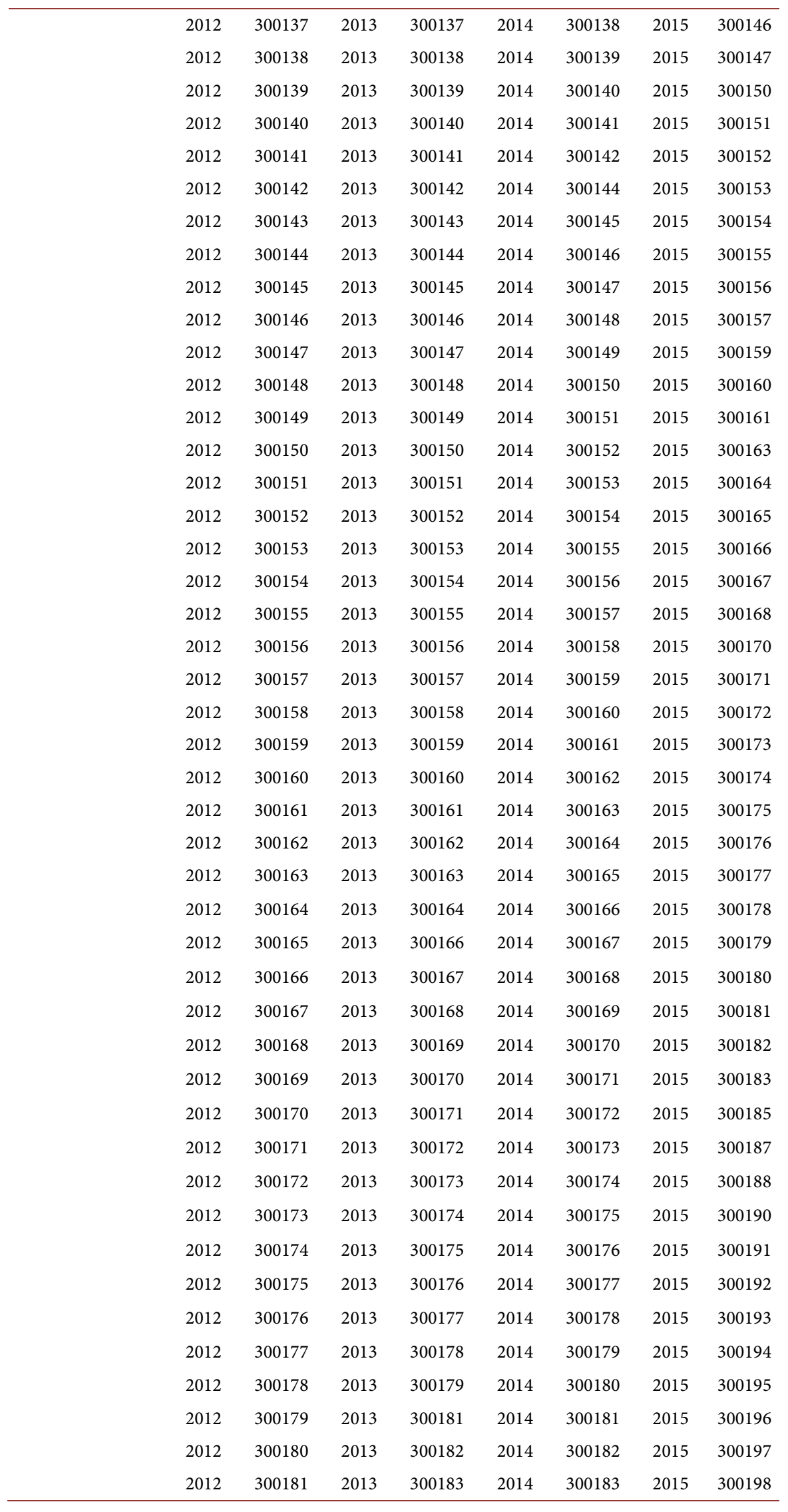




\begin{tabular}{|c|c|c|c|c|c|c|c|}
\hline 2012 & 300182 & 2013 & 300184 & 2014 & 300184 & 2015 & 300199 \\
\hline 2012 & 300183 & 2013 & 300185 & 2014 & 300185 & 2015 & 300200 \\
\hline 2012 & 300184 & 2013 & 300187 & 2014 & 300187 & 2015 & 300201 \\
\hline 2012 & 300185 & 2013 & 300188 & 2014 & 300188 & 2015 & 300202 \\
\hline 2012 & 300187 & 2013 & 300189 & 2014 & 300189 & 2015 & 300203 \\
\hline 2012 & 300188 & 2013 & 300190 & 2014 & 300190 & 2015 & 300204 \\
\hline 2012 & 300189 & 2013 & 300191 & 2014 & 300191 & 2015 & 300205 \\
\hline 2012 & 300190 & 2013 & 300192 & 2014 & 300192 & 2015 & 300206 \\
\hline 2012 & 300191 & 2013 & 300193 & 2014 & 300193 & 2015 & 300207 \\
\hline 2012 & 300192 & 2013 & 300194 & 2014 & 300194 & 2015 & 300208 \\
\hline 2012 & 300193 & 2013 & 300195 & 2014 & 300195 & 2015 & 300209 \\
\hline 2012 & 300194 & 2013 & 300196 & 2014 & 300196 & 2015 & 300210 \\
\hline 2012 & 300195 & 2013 & 300197 & 2014 & 300197 & 2015 & 300211 \\
\hline 2012 & 300196 & 2013 & 300198 & 2014 & 300198 & 2015 & 300212 \\
\hline 2012 & 300197 & 2013 & 300199 & 2014 & 300200 & 2015 & 300213 \\
\hline 2012 & 300198 & 2013 & 300200 & 2014 & 300201 & 2015 & 300214 \\
\hline 2012 & 300199 & 2013 & 300201 & 2014 & 300202 & 2015 & 300215 \\
\hline 2012 & 300200 & 2013 & 300202 & 2014 & 300203 & 2015 & 300216 \\
\hline 2012 & 300201 & 2013 & 300203 & 2014 & 300204 & 2015 & 300217 \\
\hline 2012 & 300202 & 2013 & 300204 & 2014 & 300205 & 2015 & 300218 \\
\hline 2012 & 300203 & 2013 & 300205 & 2014 & 300206 & 2015 & 300219 \\
\hline 2012 & 300204 & 2013 & 300206 & 2014 & 300207 & 2015 & 300220 \\
\hline 2012 & 300205 & 2013 & 300207 & 2014 & 300208 & 2015 & 300221 \\
\hline 2012 & 300206 & 2013 & 300208 & 2014 & 300209 & 2015 & 300223 \\
\hline 2012 & 300207 & 2013 & 300209 & 2014 & 300210 & 2015 & 300224 \\
\hline 2012 & 300208 & 2013 & 300210 & 2014 & 300211 & 2015 & 300225 \\
\hline 2012 & 300209 & 2013 & 300211 & 2014 & 300212 & 2015 & 300226 \\
\hline 2012 & 300211 & 2013 & 300212 & 2014 & 300213 & 2015 & 300227 \\
\hline 2012 & 300213 & 2013 & 300213 & 2014 & 300214 & 2015 & 300228 \\
\hline 2012 & 300214 & 2013 & 300214 & 2014 & 300215 & 2015 & 300229 \\
\hline 2012 & 300215 & 2013 & 300215 & 2014 & 300216 & 2015 & 300230 \\
\hline 2012 & 300216 & 2013 & 300216 & 2014 & 300217 & 2015 & 300231 \\
\hline 2012 & 300217 & 2013 & 300217 & 2014 & 300218 & 2015 & 300232 \\
\hline 2012 & 300218 & 2013 & 300218 & 2014 & 300219 & 2015 & 300234 \\
\hline 2012 & 300219 & 2013 & 300219 & 2014 & 300220 & 2015 & 300235 \\
\hline 2012 & 300220 & 2013 & 300220 & 2014 & 300221 & 2015 & 300236 \\
\hline 2012 & 300221 & 2013 & 300221 & 2014 & 300222 & 2015 & 300237 \\
\hline 2012 & 300222 & 2013 & 300222 & 2014 & 300223 & 2015 & 300238 \\
\hline 2012 & 300223 & 2013 & 300223 & 2014 & 300224 & 2015 & 300239 \\
\hline 2012 & 300224 & 2013 & 300224 & 2014 & 300225 & 2015 & 300240 \\
\hline 2012 & 300225 & 2013 & 300225 & 2014 & 300226 & 2015 & 300241 \\
\hline & & 2013 & 300226 & 2014 & 300227 & 2015 & 300242 \\
\hline & & 2013 & 300227 & 2014 & 300228 & 2015 & 300243 \\
\hline & & 2013 & 300228 & 2014 & 300229 & 2015 & 300244 \\
\hline & & 2013 & 300229 & 2014 & 300230 & 2015 & 300245 \\
\hline
\end{tabular}


N. B. Cao

Continued

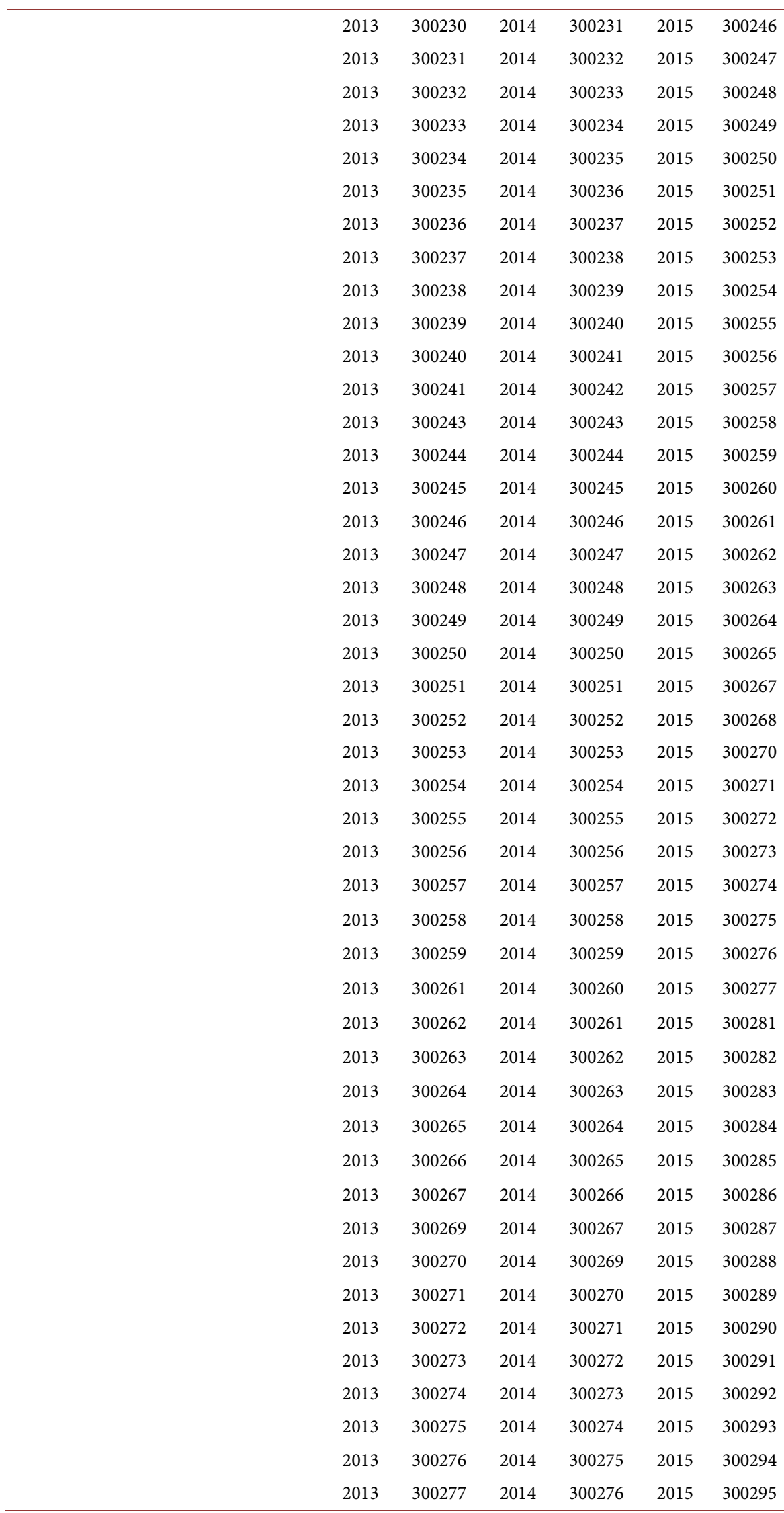




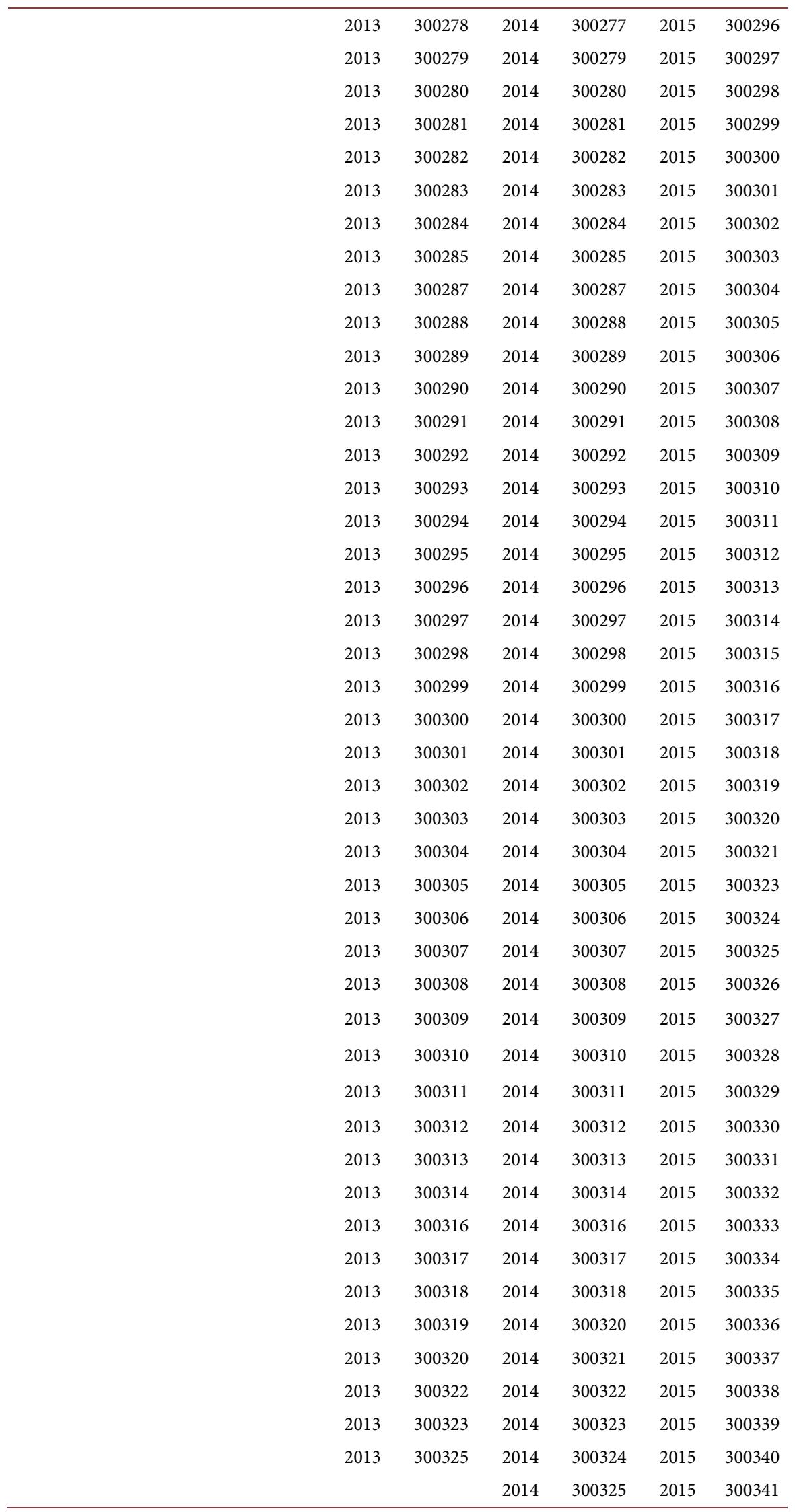


N. B. Cao

\section{Continued}

\begin{tabular}{|c|c|c|c|}
\hline 2014 & 300326 & 2015 & 300342 \\
\hline 2014 & 300327 & 2015 & 300344 \\
\hline 2014 & 300328 & 2015 & 300345 \\
\hline 2014 & 300329 & 2015 & 300346 \\
\hline 2014 & 300330 & 2015 & 300347 \\
\hline 2014 & 300331 & 2015 & 300348 \\
\hline 2014 & 300332 & 2015 & 300349 \\
\hline 2014 & 300333 & 2015 & 300350 \\
\hline 2014 & 300334 & 2015 & 300351 \\
\hline 2014 & 300335 & 2015 & 300352 \\
\hline 2014 & 300336 & 2015 & 300353 \\
\hline 2014 & 300337 & 2015 & 300354 \\
\hline 2014 & 300338 & 2015 & 300355 \\
\hline 2014 & 300339 & 2015 & 300356 \\
\hline 2014 & 300340 & 2015 & 300357 \\
\hline 2014 & 300341 & 2015 & 300358 \\
\hline 2014 & 300342 & 2015 & 300359 \\
\hline 2014 & 300344 & 2015 & 300360 \\
\hline 2014 & 300345 & 2015 & 300362 \\
\hline 2014 & 300346 & 2015 & 300363 \\
\hline 2014 & 300347 & 2015 & 300365 \\
\hline 2014 & 300348 & 2015 & 300366 \\
\hline 2014 & 300349 & 2015 & 300367 \\
\hline 2014 & 300351 & 2015 & 300368 \\
\hline 2014 & 300352 & 2015 & 300369 \\
\hline 2014 & 300353 & 2015 & 300370 \\
\hline 2014 & 300354 & 2015 & 300371 \\
\hline 2014 & 300355 & 2015 & 300372 \\
\hline \multirow[t]{11}{*}{2014} & 300356 & 2015 & 300373 \\
\hline & & 2015 & 300374 \\
\hline & & 2015 & 300375 \\
\hline & & 2015 & 300376 \\
\hline & & 2015 & 300377 \\
\hline & & 2015 & 300378 \\
\hline & & 2015 & 300379 \\
\hline & & 2015 & 300380 \\
\hline & & 2015 & 300381 \\
\hline & & 2015 & 300382 \\
\hline & & 2015 & 300383 \\
\hline
\end{tabular}


Submit or recommend next manuscript to SCIRP and we will provide best service for you:

Accepting pre-submission inquiries through Email, Facebook, LinkedIn, Twitter, etc. A wide selection of journals (inclusive of 9 subjects, more than 200 journals)

Providing 24-hour high-quality service

User-friendly online submission system

Fair and swift peer-review system

Efficient typesetting and proofreading procedure

Display of the result of downloads and visits, as well as the number of cited articles Maximum dissemination of your research work

Submit your manuscript at: http://papersubmission.scirp.org/

Or contact me@scirp.org 